\title{
Impacts of Low-Flow and Stream-Temperature Changes on Endangered Atlantic Salmon-Current Research
}

Recent climate studies in New England and the northeastern United States have shown evidence of physical changes over time, including trends toward earlier snowmelt runoff, decreasing river ice, and increasing spring water temperatures. A U.S. Geological Survey (USGS) study funded by the National Global Warming and Wildlife Science Center will be investigating changes in summer low streamflows and stream temperatures and the potential effects of those changes on endangered Atlantic salmon populations. The study also will evaluate management options that would be most likely to mitigate the effects of any changes in streamflow and temperature.

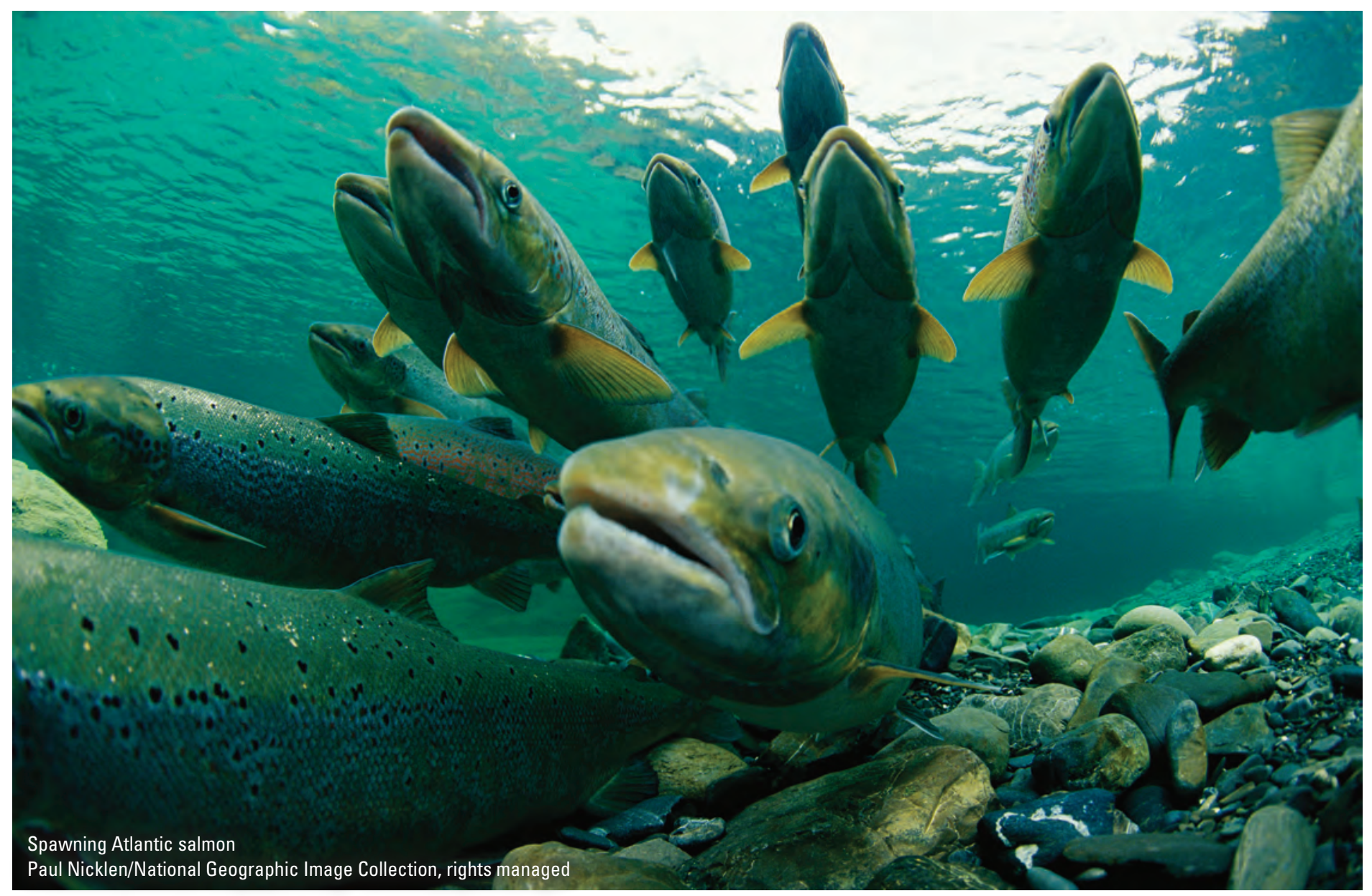

\section{Introduction}

Coastal rivers draining into the Gulf of Maine in the northeastern United States are home to Atlantic salmon (fig. 1). On November 17, 2000, The Federal government listed the Gulf of Maine Distinct Population Segment of Atlantic salmon as endangered under the Endangered Species Act. State and Federal fisheries biologists are concerned with the effects of climate-related stream- flow changes on Atlantic salmon survival in these rivers. The summer low-flow period in northeastern United States rivers and climate-related changes during this period are of particular concern because this period is critical in the Atlantic salmon life cycle.

The USGS has documented many seasonal climate-related changes in the northeastern United States during the last 30 to 150 years; these include changes toward earlier winter/spring snowmelt runoff (fig. 2), decreasing duration of ice on rivers and lakes, decreasing ratio of snowfall to total precipitation, and denser and thinner late-winter snowpack. All of these changes are consistent with warming winter/spring air temperatures (Hodgkins and Dudley, 2006a; Hodgkins and Dudley, 2006b; Hodgkins and others, 2005; Dudley and Hodgkins, 2002; Hodgkins and others, 2002; Huntington 


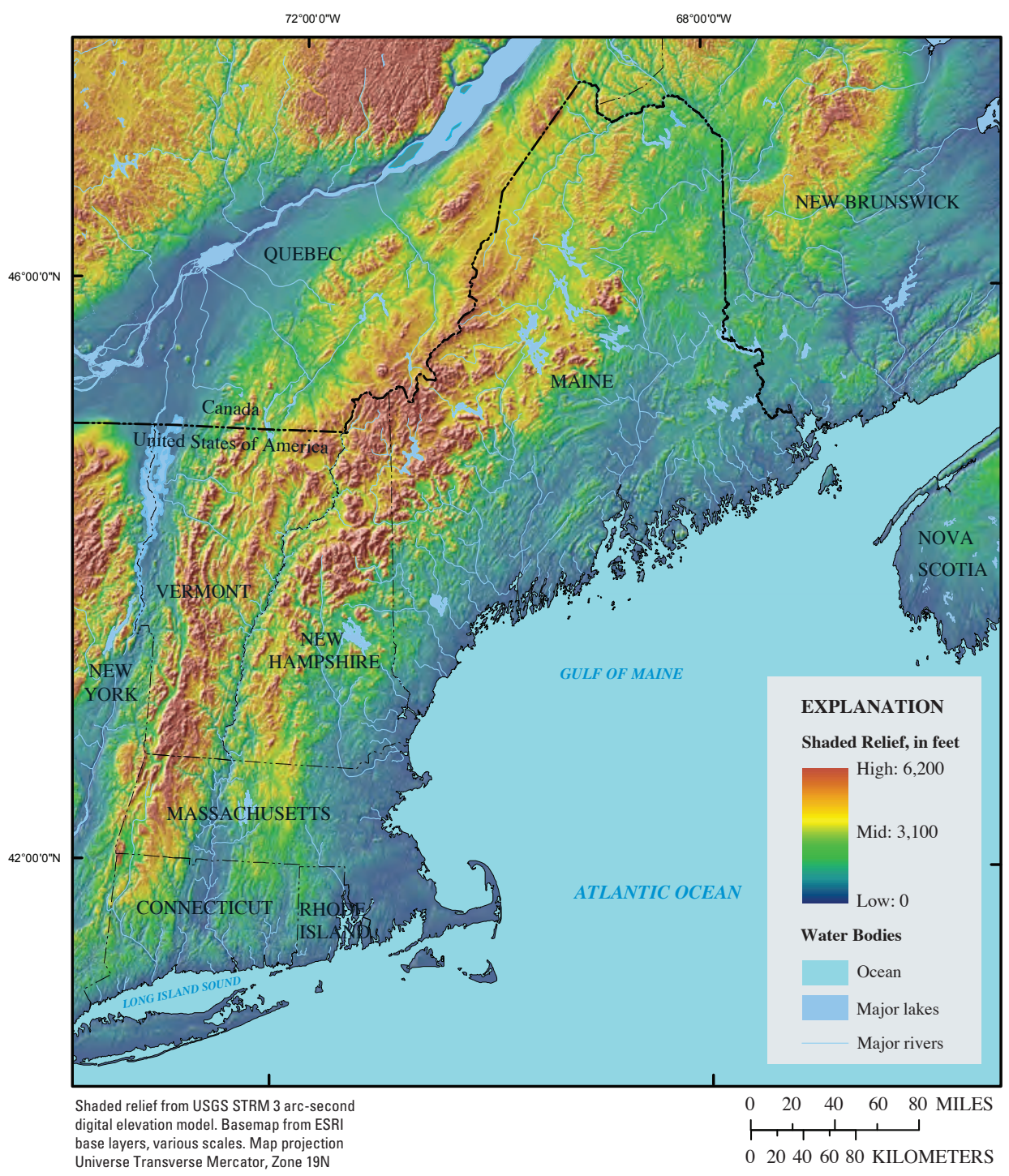

Figure 1. Northeastern coastal rivers are at the southern extent of the Atlantic salmon's geographical range; as a result, Atlantic salmon in these rivers are expected to be particularly sensitive to changes in climate.

and others, 2004). Climate-model projections for the Northeast indicate airtemperature warming, earlier snowmelt runoff, increases in annual evaporation, and decreased low streamflows (Hayhoe and others, 2007).

Spring snowmelt in the northeastern United States is important to the recharge of ground-water supplies. Following spring recharge, ground water discharges into streams throughout the summer. This discharge is a source of cool water during the summer and composes a large proportion of the streamflow during summer low-flow periods. A recession in streamflow from spring to late summer is typical in the Northeast. With snowmelt occurring earlier, the recession may

\section{Study Approach}

The USGS will be assessing historical changes in ground-water discharge to rivers in the Gulf of Maine area and estimating future groundwater discharge by using climate-model output and detailed watershed models of selected rivers in the study area. USGS researchers also will be completing development of a salmon population dynamics model to estimate Atlantic salmon survival as a function of potential future changes in ground-water discharge and in-stream temperature.

To assess historical changes in ground-water discharge, USGS researchers will be analyzing records of flow for rural, unregulated streams with at least 50 years of continuous record in the northeastern United States and selected areas in the Canadian provinces of Quebec and New Brunswick. The stormflow component of the total streamflow will be separated from the groundwater-discharge component. Timing, magnitude, and duration statistics will be derived from the resulting ground-water discharge records and will be analyzed to quantify any changes that have occurred over the periods of record.

In an effort to project future changes for summer low-flow conditions in the Northeast, watershed models will be constructed by using the USGS Precipitation Runoff Modeling System. The models will be calibrated to the historical record with special emphasis on the summer low-flow periods, when the ratio of ground-water discharge to total streamflow is greatest. Future estimates of streamflows, stream temperatures, and ground-water discharge to streamflow during the critical low-flow periods for Atlantic salmon will be simulated by using climate-model output as described in the Intergovernmental Panel on Climate Change Fourth Assessment Special Report on Emission Scenarios (Nakicenovic and Swart, 2000).

Watershed-model output describing future flow and in-stream temperature estimates will be used in conjunction with the USGS salmon-survival model to describe future scenarios of salmonpopulation dynamics. Specific results will include the number and size of emigrating salmon and the numbers of adult salmon returning to their home rivers to spawn, in addition to estimates 


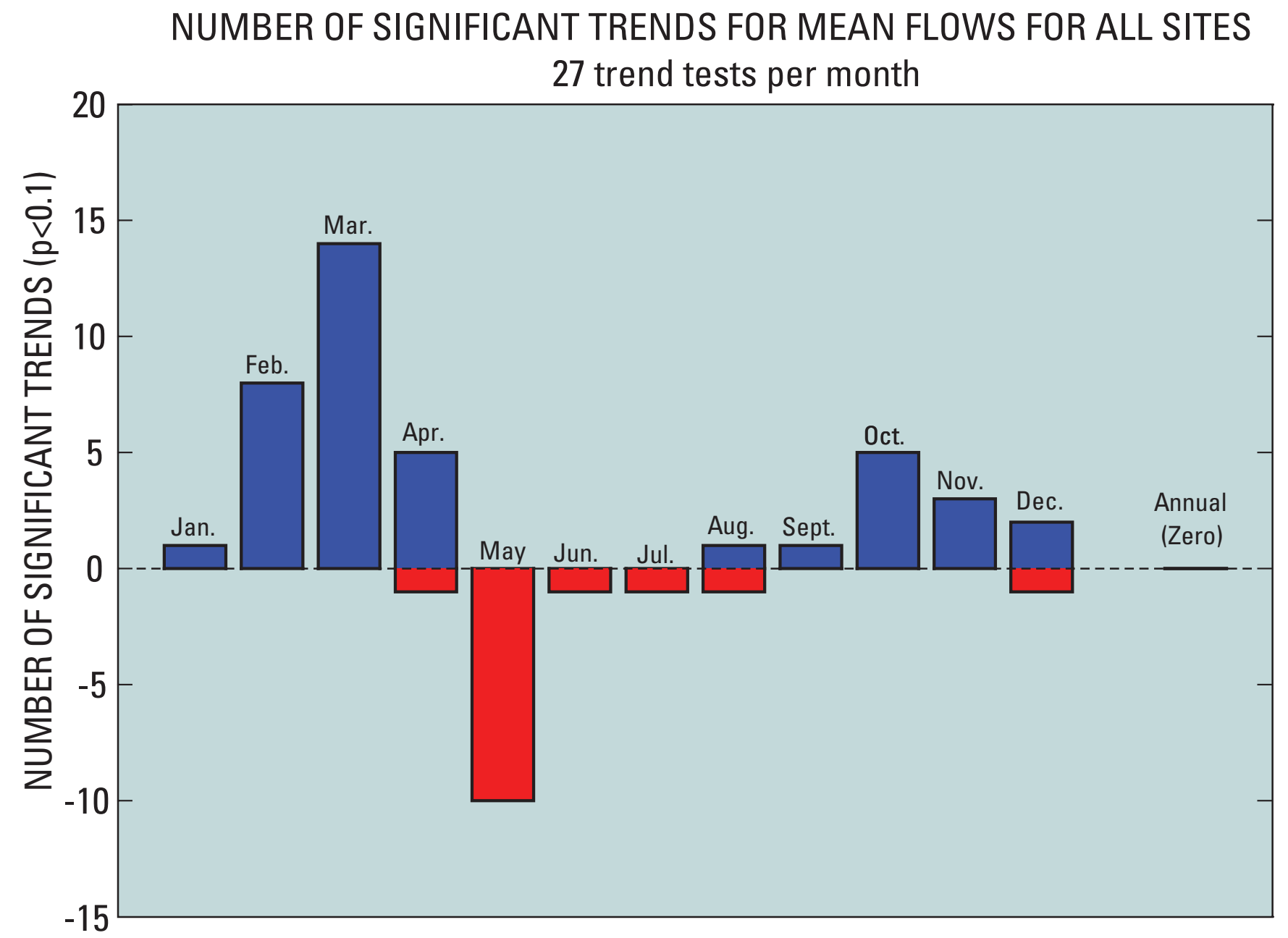

TIME PERIOD

Figure 2. Number of significant changes in monthly streamflow magnitudes over time (average of 71 years through 2002) for streamflowgaging stations in New England. Increasing streamflows in February, March, and April and decreasing streamflows in May are supporting evidence of a shift in timing toward earlier winter/spring runoff (from Hodgkins and Dudley, 2005).

of population growth and survival. The model output also will allow estimation of the effects of different management strategies (for example, stocking strategies and habitat manipulation), and evaluation of the consequences of choosing each strategy to determine which would be most likely to mitigate the effects of streamflow and streamtemperature changes.

\section{Benefits}

Much recent progress has been made in describing hydrologic changes in the Northeast during the last century and the life cycle and population dynamics of Atlantic salmon. Little progress, however, has been made in quantitatively determining the physical and biological effects of documented hydrologic changes in such variables as the timing of winter/ spring snowmelt runoff. This research will add substantially to the existing knowledge of the effects of changing climate on an endangered fish species and will contribute to the body of science necessary to allow managers to manage entire ecosystems and physical systems in the Northeast effectively in the face of short-term variability and long-term changes in climate.

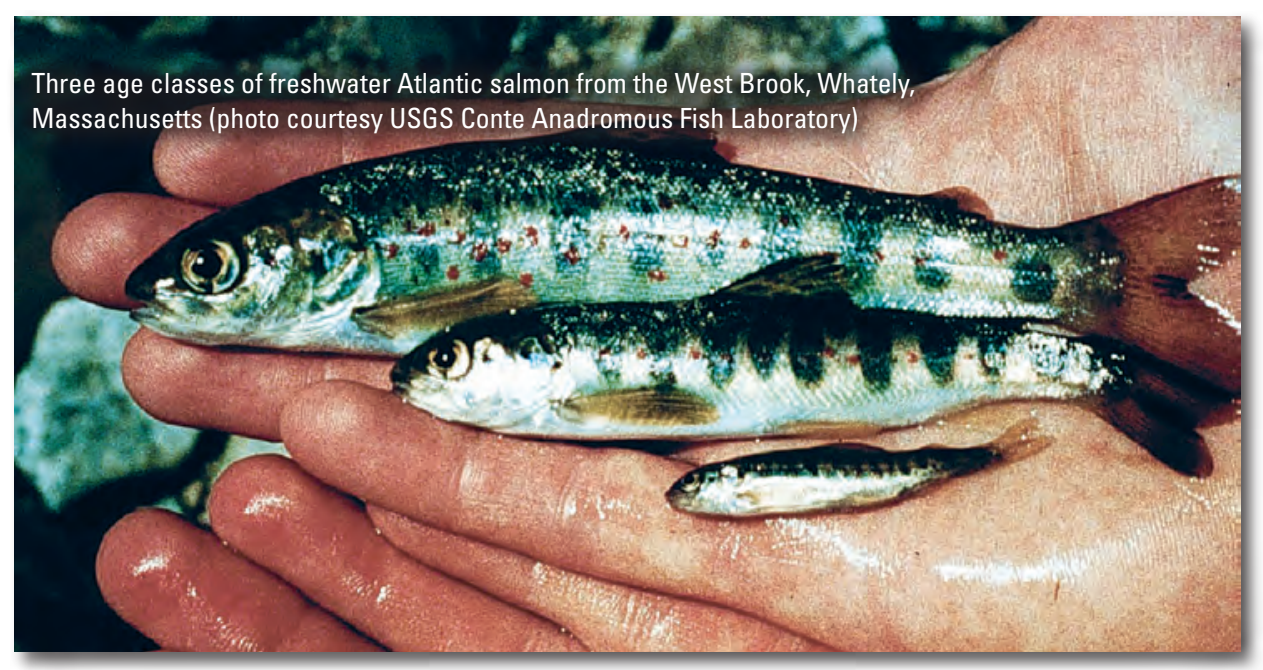




\section{Geographic coverage for two watershed models in coastal Maine}

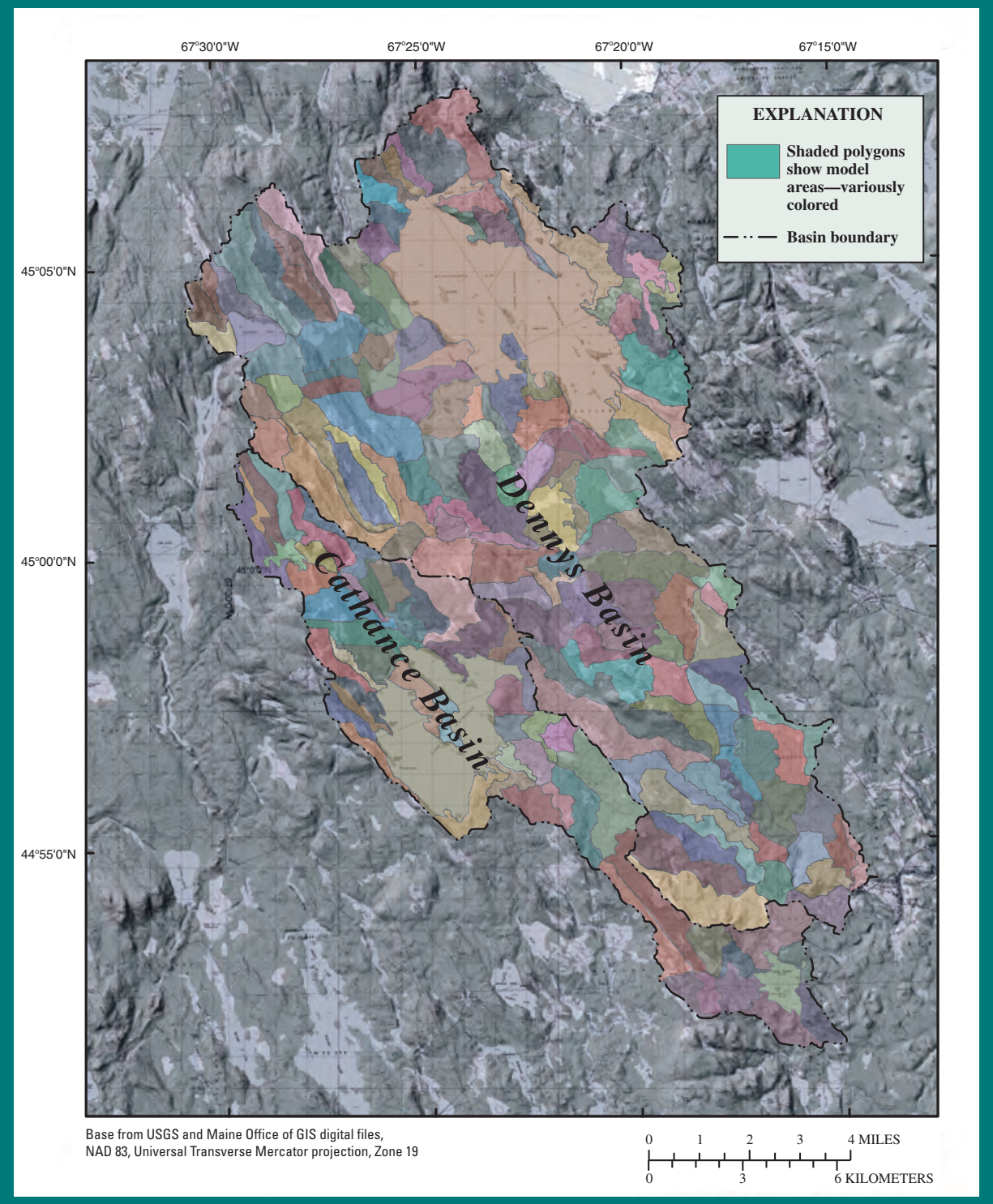

\section{References}

Dudley R.W., and Hodgkins, G.A., 2002,

Trends in streamflow, river ice, and snow pack for coastal river basins in Maine during the 20th century: U.S. Geological Survey Water-Resources Investigations Report 02-4245, 26 p.

Hayhoe, K., Wake, C.P., Huntington, T.G., Luo, L., Schwartz, M., Sheffield, J., Wood, E., Anderson, B., Bradbury J., DeGaetano, A., Troy, T., and Wolfe D., 2007, Past and future changes in climate and hydrological indicators in the U.S. Northeast: Climate Dynamics, v. 28, p. 381-407.

Hodgkins, G.A., and Dudley, R.W., 2005, Changes in the magnitude of annual and monthly streamflows in New England, 1902-2002: U.S. Geological 2005-5135, 37 p.

Hodgkins, G.A., and Dudley, R.W., 2006a, Changes in late-winter snowpack depth, water equivalent, and density in Maine, 1926-2004: Hydrological Processes, v. 20, p. 741-751.

Hodgkins, G.A., and Dudley, R.W., 2006b, Changes in the timing of winter-spring streamflows in eastern North America, 1913-2002: Geophysi-
Hodgkins, G.A., Dudley, R.W., and Huntington, T.G., 2005, Changes in the number and timing of days of ice-affected flow on northern New England rivers, 1930-2000: Climatic Change, v. 71, p. 319-340.

Hodgkins, G.A., James, I.C., II, and Huntington, T.G., 2002, Historical changes in lake ice-out dates as indicators of climate change in New England, 1850-2000: International Journal of Climatology, v. 22, p. 1819-1827.

Huntington, T.G., Hodgkins, G.A., Keim, B.D., and Dudley, R.W., 2004, Changes in the proportion of precipitation occurring as snow in New England (1949 to 2000): Journal of Climate, v. 17 , p. 2626-2636.

Letcher, B.H., Dubreuil, T.D., O’Donnell, M.J., Obedzinski, M., Griswold, K., and Nislow, K.H., 2004, Long-term consequences of variation in timing and manner of fry introduction on juvenile Atlantic salmon growth, survival and life history expression: Canadian Journal of Fisheries and Aquatic Sciences, v. 61, p. 2288-2301.

Letcher, B.H., Gries, G., and Juanes, F., 2002, Survival of stream-dwelling Atlantic salmon-Effects of life history variation, season and age: Transactions of the American Fisheries Society, v. 131, p. 838-854.

Letcher, B.H., Nislow, K.H., Coombs, J., O’Donnell, M.J., and Dubreuil, T.L., 2007, Population response to habitat fragmentation in a brook trout population: PloS One, 2(11): e1139. doi:10.1371/journal.pone.0001139. Survey Scientific Investigations Report cal Research Letters, v. 33: L06402, doi 10.1029/2005GL025593.
Nakicenovic, N., and Swart, R., eds., 2000, IPCC special report on emissions scenarios: Cambridge, U.K., and New York, N.Y., Cambridge University Press, 570 p.

-By Robert W. Dudley, Glenn A. Hodgkins, and Benjamin H. Letcher

For more information please contact:

Director, USGS Maine Water

Science Center

196 Whitten Road

Augusta, Maine 04330

Telephone: (207) 622-8201

Email:dc_me@usgs.gov

Web site: http://me.water.usgs.gov 